\title{
INVESTIGATING THE CONCEPT OF “LIGHTNESS” AS REFLECTED IN THE RUSSIAN-SPEAKING UKRAINIANS’ LINGUISTIC CONSCIOUSNESS
}

\author{
Iia Gordienko-Mytrofanova \\ ORCID 0000-0001-5332-066 \\ ikavgm@gmail.com \\ Hryhorii Skovoroda Kharkiv National Pedagogical University, Ukraine \\ Iuliia Kobzieva \\ ORCID 0000-0001-8483-9695 \\ Scopus Author ID: 57215587708 \\ yu.kobzeva88@gmail.com \\ Hryhorii Skovoroda Kharkiv National Pedagogical University, Ukraine \\ Kateryna Borokh \\ ORCID 0000-0001-5849-2798 \\ katya.borokh.85@gmail.com \\ Hryhorii Skovoroda Kharkiv National Pedagogical University, Ukraine
}

Received March 2, 2020; Revised April 24, 2020; Accepted May 21, 2020

\begin{abstract}
The purpose of this study is to define and describe the semantic components of the verbalised concept "lightness" as a component of ludic competence in the linguistic consciousness of the Russian-speaking people from Eastern Ukraine. The main method of the research was a psycholinguistic experiment. The sample comprised 426 young people (aged 18-35), males and females being equally represented. Cluster analysis showed that the core of the concept "lightness" is represented by three semantic groups: "the quality being light and insignificant in weight and size ...", "the feeling of happiness and joyful ease", "the feeling of freedom ..., cheerfulness, excitement". The last two clusters reveal the ambivalent nature of the concept "lightness". The concept "lightness" is characterized by a large variety of peripheral clusters. The ones that are especially noteworthy are "insight" and "duality". The former reflects the cognitive component of lightness, which accounts for 3 per cent. The latter reflects the concept's ambivalent nature. Basically, the semantic content of the core of the word "lightness" does not depend on gender. The comparative analysis of the concept "lightness" in the linguistic consciousness of Ukrainian citizens and people living in Russia reveals its nationally-specific perception in the linguistic consciousness of Ukrainian people, which was reflected in the most frequent reaction "freedom". Taken together, both samples share a number of common features: wide semantic scope; strong synonymic and weak antonymic connections between stimulus and reactions; positive emotional response to the stimulus. Finally, the results of the free word association test with the stimulus word "lightness" were successfully used to
\end{abstract}

(C) Gordienko-Mytrofanova, Iia; Kobzieva, Iuliia, Borokh, Kateryna, 2020. This is an Open Access article distributed under the terms and conditions of the Creative Commons Attribution 4.0 International Licence (https://creativecommons.org/licenses/by/4.0/).

East European Journal of Psycholinguistics, 7(1), 48-65. https://doi.org/10.29038/eejpl.2020.7.1.gor 
define more precisely and expand our understanding of "lightness" as a component of ludic competence taking into account both core and peripheral clusters.

Keywords: ludic competence, playfulness, ludic position, lightness, psycholinguistic experiment, free word association test, linguistic consciousness.

Гордіснко-Митрофанова Ія, Кобзєва Юлія, Борох Катерина. Концепт «легкість» у мовній свідомості російськомовних українців.

Анотація. Мета дослідження - виявити й описати семантичні компоненти вербалізованого концепту «легкість», як компонента ігрової компетентності, в мовній свідомості російськомовних жителів Східної України. Основним методом дослідження був психолінгвістичний експеримент. Вибірку склало 426 респондентів молодого віку (18-35) у рівному співвідношенні чоловіків і жінок. Результати кластерного аналізу показали, що ядро концепту «легкість» представлено трьома семантичними групами: «властивість чогось легкого, незначного за вагою й розміром...», «почуття щастя й радісного спокою», «почуття свободи..., бадьорості, підйому». Два останніх кластери відображають амбівалентний характер концепту «легкість». Концепт «легкість» характеризується великою різноманітністю периферійних кластерів. Серед них заслуговують на увагу два кластери - «інсайт» і «дуальність». У першому відображена когнітивна складова легкості, яка склала $3 \%$. У другому - амбівалентний характер концепту. Семантичне наповнення ядра слова «легкість» загалом не залежить від статевої належності. Порівняльний аналіз концепту «легкість» у мовній свідомості жителів України й жителів Росії дає змогу твердити про його національно-типологічне сприйняття в мовній свідомості жителів України, що знайшло своє втілення в найбільш високочастотній реакції «свобода». Загалом обидві вибірки характеризуються: широким семантичним спектром; сильними синонімічними та слабкими антонімічними зв'язками стимулу й реакцій; позитивними емоціями на стимул. Нарешті, результати вільного асоціативного експерименту зі стимулом «легкість» було успішно використано з метою смислового уточнення й розширення поняття «легкість» як компонента ігрової компетентності.

Ключові слова: ігрова компетентність, грайливість, ігрова позищія, легкість, психолінгвістичний експеримент, вільний асоціативний експеримент, мовна свідомість.

\section{Introduction}

This article is part of the joint research effort dedicated to ludic competence (Gordienko-Mytrofanova \& Kobzieva, 2017; Gordienko-Mytrofanova, Pidchasov, Sauta, \& Kobzieva, 2018). We define ludic competence as a system if inner resources to which a person turns in order to balance their personality against external conditions of the social environment on the basis of positive emotions, e.g. interest and joy, which are frequently expressed in a very emotional way, accompanied by tension and excitement.

Ludic competence is formed alongside the development of playfulness, which is a stable personality trait and has been subject of scientific research since 1975 (Csikszentmihalyi, 1975; Groos, 1976; Chapman, 1978; Bowman, 1987; Barnett, 1990; Bundy, 1996; Schaefer \& Greenberg, 1997; Guitard, Ferland, Dutil, 2005; Shen, 2010; Yarnal \& Qian, 2011; Proyer, 2012; Yue et al., 2016; Gordienko-Mytrofanova \& Kobzieva, 2017).

We define playfulness as a person's creative adaptation to the reality of their own "Self" (individual identity) and to the reality of the World (social identity). As a result, every difficult situation can be faced as a challenge, rather than a threat (Gordienko- 
Mytrofanova \& Kobzieva, 2017; Guitard et al., 2005, p. 19).

In Ukraine, we are pioneers among scholars in studying playfulness. We study it with the help of psycholinguistic methods and psycholinguistic experiment in particular, whose major part is free word association test. Previously, we undertook the most extensive longitudinal free word association test with the stimulus word "playfulness" (4,795 respondents). Then, in order to explore common tendencies and characteristic features of the general population (which is the whole population of Ukraine aged 1875 who are fluent in Russian) and to meet the objectives of this research, several samples were formed. Nineteen psycholinguistic meanings of playfulness were described as a result of the psycholinguistic experiment with a sample of 1,600 respondents.

Relying on previous theoretical and empirical research into playfulness as a personality trait (Barnett, 2007; Guitard et al., 2005; Proyer, 2012; Yarnal \& Qian, 2011; Yue et al., 2016), as well as analysis of components/scales of playfulness (Glynn \& Webster, 1992; Tsuji et al., 1996; Schaefer \& Greenberg, 1997; Barnett, 2007; Yarnal \& Qian, 2011; Proyer, 2012; Shen, Chick, \& Zinn, 2014; Proyer, 2017), highfrequency reactions of the biggest sample of 4,795 respondents and established psycholinguistic meanings, we managed to single out the following components of playfulness: sensitivity, imagination, sense of humour, lightness, flirting, impishness, fugue (Gordienko-Mytrofanova \& Kobzieva, 2017; Gordienko-Mytrofanova et al., 2018; 2019).

The components of playfulness as an integral personality trait are also the components of ludic competence. We define them as "motivational predisposition" (Raven, 2001). This "motivational predisposition" forms the basis of ludic positions of effective social interaction: "sensitivity" (sensitive) - "Aesthete"; "imagination" "Sculptor"; "lightness" ("light”) - "Balance-Master"; "flirting” (flirtatious) "Diplomat”; "impishness" (impish) - "Frolicsome Fellow”; "humour” (funny) - "Real Humourist"; "fugue" (fugue) - "Holy Fool”. Ludic positions reflect the way how ludic competence manifests itself in different standard and non-standard situations, which brings about behavioural aspect. Therefore, mastering ludic positions means mastering certain behavioural patterns.

The names of ludic positions are justified both theoretically and empirically (Gordienko-Mytrofanova et al., 2018) and were tested during coaching sessions in ludic competence, which are part of the curriculum of psychology students at H.S. Skovoroda Kharkiv National Pedagogical University, Ukraine.

As it was mentioned above, lightness is one of the components of ludic competence. Lightness is not part of any scales designed to measure playfulness that we are aware of: Adult Playfulness Scale (Glynn, \& Webster, 1993); Playfulness Scale for Adults (Schaefer \& Greenberg, 1997); Playfulness Scale for Young Adults (Barnett, 2007); Older Adult Playfulness Scale (Yarnal \& Qian, 2011); Short Measure of Adult Playfulness (Proyer, 2012); Adult Playfulness Trait Scale (Shen et al., 2014); Otherdirected, Lighthearted, Intellectual, and Whimsical playfulness (Proyer, 2017). 
However, as it was mentioned above, lightness as a component of playfulness / ludic competence was discovered as we described the psycholinguistic meanings of playfulness with a sample of 1,600 respondents (Gordienko-Mytrofanova et al., 2019).

We decided to study lightness as a component of ludic competence from a psycholinguistic approach, using free word association test as a psycholinguistic tool for clarifying and expanding our understanding of the semantic content of notions that are expressed in the language with the help of particular words. Free word association test has already proved to be very effective in studying impishness, imagination, humour as components of ludic competence, as well as studying holy fool as a ludic position (Gordienko-Mytrofanova et al., 2018; Kobzieva, Gordienko-Mytrofanova, \& Goncharenko-Kulish, 2020a; Kobzieva, Gordienko-Mytrofanova, \& Sauta, 2020b; Kobzieva, Gordienko-Mytrofanova, Udovenko, \& Sauta, 2020c).

In our coaching sessions dedicated to ludic competence, we use the results of the psycholinguistic experiment that help us consider gender-specific differences in the perception of certain component of playfulness / ludic competence expressed with the help of a particular word, emotional attitude to this word, as well as its popular meanings that are typical of the linguistic consciousness of the Russian speakers in Ukraine.

Linguistic consciousness is coined as "the aggregate of psychological mechanisms of speech generation and understanding, as well as retaining the language in consciousness, i.e., mental mechanisms that underlie a person's speech activity" (Popova \& Sternin, 2007, p. 32). It should be noted that this approach describes linguistic consciousness from the perspective of psycholinguistics, science with the human linguistic consciousness in the context of its psychological reality as an exclusive object of study (Sternin \& Rudakova, 2011; Zasiekina, 2008).

The associative field obtained in the course of association experiment is "not only a fragment of the verbal memory of a human being, but also a fragment of the image of the world shared by a particular ethnos, reflected in the consciousness of an average representative of some particular culture, their motives and judgments, and, consequently, cultural stereotypes” (Ufimtseva, 2009, p. 98). The scope and nature of reactions in associative fields tell us a lot about the word usage, revealing the content of the word which is psychologically common among the native speakers of the language.

The present article describes the results of a joint research effort (2017-2019) into the stimulus "lightness" that was conducted by K. Borokh, M. Kosenko, Iu. Kobzieva under the supervision of I. Gordienko-Mytrofanova on the basis of the Department of Applied Psychology at H. S. Skovoroda Kharkiv National Pedagogical University.

The aim of the present article is to use the method of applied psycholinguistic research to define semantic components of the verbalised concept "lightness" in the linguistic consciousness of young Russian-speaking people living in Ukraine. 
The results of the research will be later used 1) to define lightness as a component of ludic competence and as playfulness scale in the questionnaire that we are developing on the basis of cluster analysis results; 2) to describe behavioural pattern of the ludic position "Balance-Master" taking into account meanings that reflect the linguistic consciousness of Russian native speakers.

The following objectives were outlined: to determine general features of the verbal behaviour of young respondents in the framework of studying the verbalised concept "lightness"; to suggest major strategies and ways of dividing associations triggered by the stimulus "lightness" into clusters.

\section{Methods}

The main method of this research is a psycholinguistic experiment, whose major part is free word association test with the stimulus word "lightness". As additional methods, we used surveys (to refine the results of the free word association test) and questionnaires (to specify the characteristics of the sample). As a mathematicalstatistical method to analyze the results of the research, we used frequency and cluster analysis, which allowed us to identify tendencies in the distribution of associations expressed by the experimental group.

The free word association test with the stimulus word "lightness" was conducted in written form. Respondents were instructed to state their gender, age, education/specialisation, marital status, and write down the first five words that came to their minds that were somehow associated with the word "lightness".

The total number of respondents was 426 young people (18-35 y.o.), males and females being equally represented. By education, $76.7 \%$ had a university degree, $3 \%$ were undergraduate students, $13.8 \%$ completed secondary school education, and $6.5 \%$ did not state their education. By marital status, $69.9 \%$ were married, $0.7 \%$ cohabited with a partner, $2.3 \%$ had a girlfriend or boyfriend, $19.9 \%$ were single, $0.7 \%$ were divorced; $6.5 \%$ did not state their marital status.

\section{The study}

\subsection{Building associative fields for five reactions and for the first reaction}

Frequency analysis of the free word association test with the stimulus word "lightness" enabled us to build associative fields for five reactions and for the first reaction. A total of 1,645 reactions were expressed by the respondents (the results of the free word association test were processed for five reactions). Out of these, 747 reactions were unique ${ }^{3}$, including 153 word combinations and complete sentences, 267 reactions with a frequency greater than one, 480 isolated cases ${ }^{4}, 0$ declined to answer the question.

\footnotetext{
${ }^{3}$ Unique reactions are reactions expressed with different lexemes (Karaulov, 2002a).

4 Isolated cases are reactions with a frequency that equals 1 (Karaulov, 2002a).
} 
As far as the first reaction is concerned, the free word association test with the stimulus word "lightness" yielded 426 associations, of which 226 reactions were unique, including 34 word combinations; 68 reactions with a frequency greater than one, 158 isolated cases, 0 declined to answer the question.

Comparative analysis of the associative fields (for the first and for five additional reactions) prompted the conclusion that the scope and nature of reactions have not changed significantly. What has changed, though, is the sequence of high-frequency reactions (Fig. 1), as well as the quantity of peripheral reactions and isolated cases. The latter can be easily explained by the bigger number of respondents.

Figure 1

Comparative analysis of the associative fields for the first and for five additional reactions to the stimulus word "lightness"

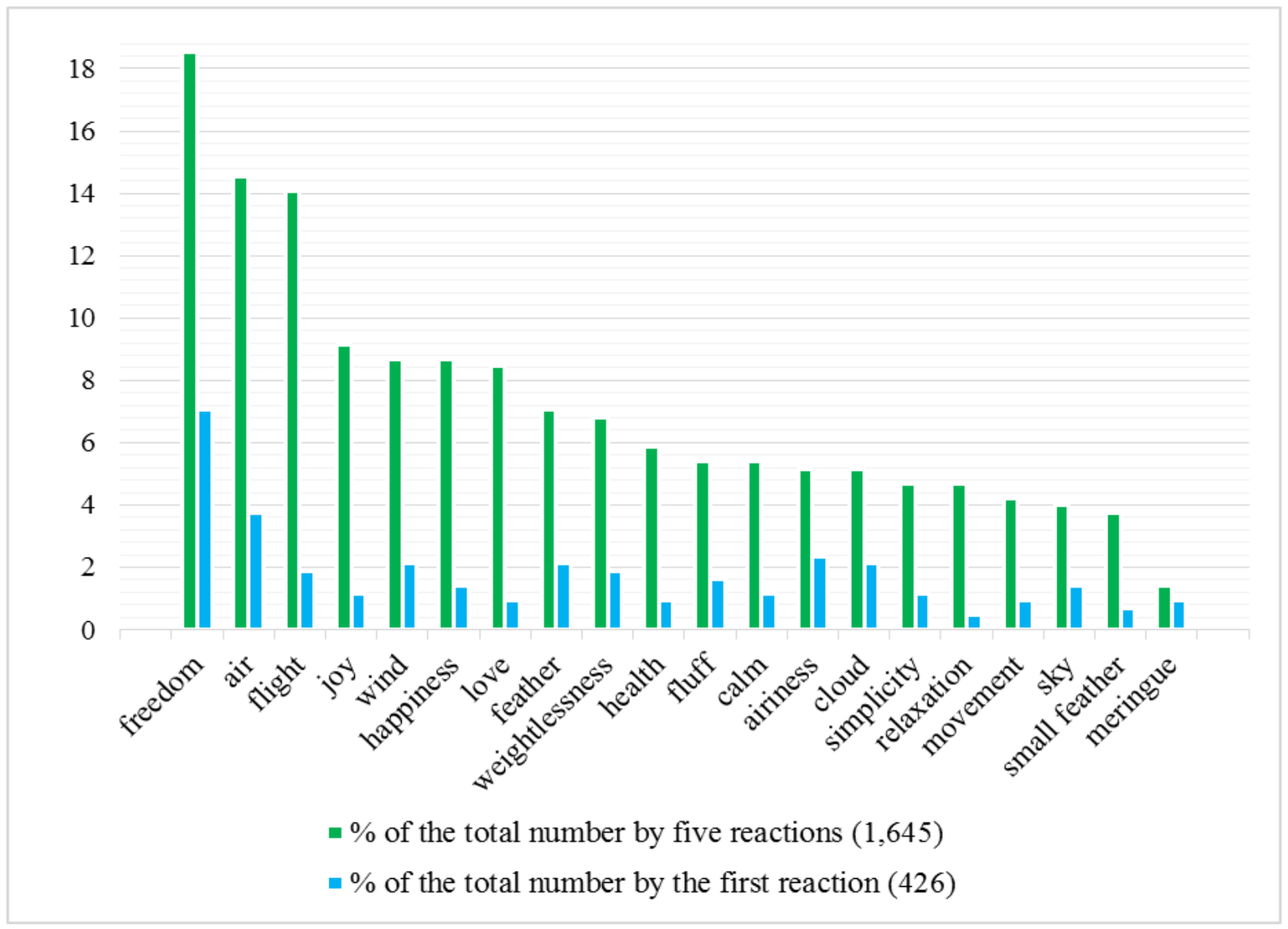

\begin{abstract}
3.2. Partial semic interpretation of the results of the frequency analysis for the free word association test with the stimulus word "lightness" according to the first reaction

Partial semic interpretation of the results of the frequency analysis for the free word association test with the stimulus word "lightness" according to the first reaction was the next stage of our research. Partial semic interpretation of associative reactions
\end{abstract}


involves combining cognate associations and nominations of the same semantic component expressed by different parts of speech, including singular and plural forms of the same word.

Partial semic interpretation allows us to obtain more objective data on highfrequency associations and the quantity of different sememes that were revealed during the experiment. For example, feather 14 [feather 9, small feather 3, white feather, white feather in weightlessness 1], cloud 10 [cloud 9, clouds 1], fluff 11 [fluff 7, bit of fluff 3, poplar fluff 1], weightlessness 9, [weightlessness 8, weightless 1]. Analysis of the data from partial semic interpretation resulted in a changed sequence of some highfrequency associations in comparison with the reactions. However, the composition and nature of the associations remained the same.

\subsection{General features of the verbal behaviour of the young respondents}

Partial semic interpretation allowed us to outline general features of the verbal behaviour of the young respondents (Fig. 2).

Figure 2

Comparative analysis of associations of female and male samples to the stimulus "lightness"

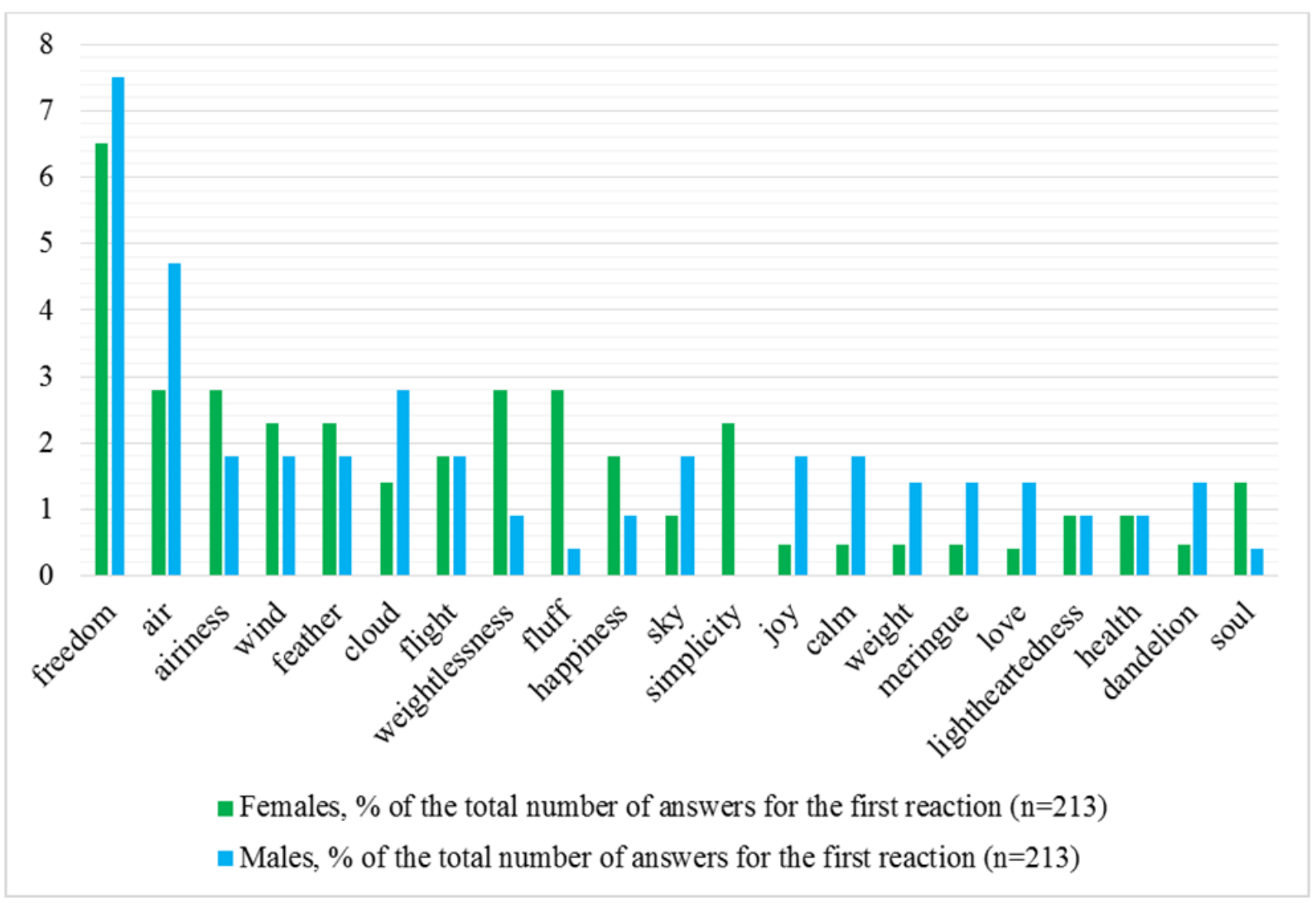


The general features of the verbal behaviour of the young respondents are represented in the following lexemes (more that 1\%): freedom 30 (7.04\%), air 16 (3.76\%), airiness 10 (2.35\%), wind, feather 9 (2.11\%), flight 8 (1.88\%).

\subsection{Negative reactions}

The associative field of the stimulus "lightness" had a number of reactions with negative connotation ${ }^{5}(1.9 \%)$. These are: couldn't-care-less attitude 2, indifference, marijuana, lying, alcohol addiction, madness, smoking 1.

The low number of negative reactions shows that the general attitude of the respondents to the stimulus "lightness" is quite positive.

3.5. Semantic clusters of the verbalised concept "lightness"

426 reactions obtained during the experiment were distributed among the following semantic groups/clusters ${ }^{6}$ :

1. Air 16, airiness 11 [airiness 10, airy shawl 1], feather 14 [feather 9 , small feather 3, white feather, white feather in weightlessness 1], cloud 10 [cloud 9, clouds 1], fluff 11 [fluff 7, bit of fluff 3, poplar fluff 1], weightlessness 9, [weightlessness 8, weightless 1], meringue, weight, dandelion 4, snow 3 [snow 2, snowflake 1], carpet, slenderness, ball 2, immaterial, scales, hydrogen, hair, helium, knee high socks, dessert, marshmallow, kefir, mosquito, basket, fur, soap bubbles, soft, dress, fluffiness, backpack, soufflé, comfortable shoes, energy consumption, ether 1 - 113 (26.5\%) f. 59 (13.85\%), m. $54(12.7)$ = “THE QUALITY BEING LIGHT AND INSIGNIFICANT IN WEIGHT AND SIZE; AIRINESS, WEIGHTLESSNESS” (indicated as "SOMETHING LIGHT" in Fig. 3).

2. Happiness 7 [happiness 6, feeling of happiness 1], sky, joy 6 [joy 5, heart full of joy 1], love [love 4, falling in love 1], calm 5, lightheartedness, soul 4, spring, comfort, silence 3, peace [peace, appeasement 1], sea, mood, tenderness, relaxation, emptiness, pleasure, hobby 2, balance, carelessness, return, all is well, completion, completed work, green grass, summer, daydream, ease of mind, finally, holiday, snowdrop, work done correctly, nature, walk, journey, relaxedness, relax, state, satisfaction 1 - 84 (19.71\%), f. 43 (10.09\%), m. 41 (9.62\%) = “THE FEELING OF HAPPINESS AND JOYFUL EASE" (indicated as "HAPPINESS” in Fig. 3).

3. Freedom 34 [freedom 30, liberation 2, taking a load off, freedom of speech 1], health 5 [health 4, healthy lifestyle 1], spontaneity 3, cheerfulness, delight, excitement

\footnotetext{
${ }^{5}$ The authors of the paper coded the reactions as positive or negative on the basis of Russian dictionaries which give information about emotional connotations of words (Dal, 2011; Ozhegov \& Shvedova, 2011; Ushakov, 1935-1940; Yefremova, 2000), e.g. ALCOHOL ADDICTION: 1. A disease that involves compulsive use of alcohol. 2. colloq. Excessive drinking (Yefremova, 2000); COULDN'T-CARE-LESS ATTITUDE slang. Careless, indifferent attitude to people and everything that happens (Yepishkin, 2010). The agreement between the researchers was 95\%.

${ }^{6}$ The reactions were distributed among various clusters on the basis of the algorithm of describing psycholinguistic meanings developed by Sternin (Sternin \& Rudakova, 2011). The author of this article, Gordienko-Mytrofanova, collaborated with Sternin during 3 years and described the psycholinguistic meanings of the stimulus word "playfulness" with a sample of 1,600 respondents under his supervision.
} 
2, opportunities, enthusiasm, independence, space, sex, courage, confidence, financial stability, vigor 1 - 57 (13.38\%), f. 28 (6.57\%), m. 29 (6.81\%) = “THE FEELING OF FREEDOM (physical or mental), CHEERFULNESS, EXCITEMENT” - (indicated as "FREEDOM" in Fig. 3).

4. Wind 12 [wind 9, light wind 2, warm wind 1], dream 3 [light and warm dream, dream, to sleep], alcohol 3 [alcohol 2, alcohol addiction 1], breeze [breeze, light breeze 1], transparence 2, aquarelle, white, flapping, light, affection, pastel, sunrise 1 29 (6.8\%), f. 18 (4.2\%), m. $11(2.6 \%)$ = “THE QUALITY OF SOMETHING INSIGNIFICANT IN ITS MANIFESTATION" - (indicated as "SOMETHING INCONSPICUOUS” in Fig. 3).

5. Flight 8, hovering 4 [hovering, to hover 2], bird 3, butterfly, hang-glider, wings, planet 1 - 19 (4.46\%), f. 9 (2.11\%), m. 10 (2.34\%) = "THE ABILITY TO MOVE OR HOVER IN AIR" - (indicated as "HOVERING" in Fig. 3).

6. Relationships 3, communication, honesty 2, amiability, benevolence, trust, unresentfulness, treatment of people, not bearing grudges, decency, condescension, character, person 1 - 18 (4.2\%), f. 5 (1.18\%), m. 13 (3.05\%) = "FEATURE OF CHARACTER OF PERSON WHO IS DECENT AND EASY TO DEAL WITH”(indicated as "FEATURE OF CHARACTER" in Fig. 3).

7. Movement 4, gait 3, ballet dancer [ballet dancer, ballet 1], jump 2, barefoot on the grass, golf, grace, legs, worship, sliding 1 - 17 (3.99\%), f. 6 (1.41\%), m. 11 (2.58\%) = “ABILITY TO MOVE GRACEFULLY”, about a person - (indicated as "GRACEFULNESS" in Fig. 3).

8. No fuss, knowledge 2, luckiness, money, magic touch, mark, victory, promotion, growth, luck, success 1 - 13 (3.05\%), f. 5 (1.17\%), m. 8 (1.88\%) = “ABILITY TO ACQUIRE SOMETHING EFFORTLESSLY, BY GOOD LUCK” - (indicated as "LUCK" in Fig. 3).

9. Simplicity 5, insight 3, inspiration, perception, availability, epiphany, clarity 1 13 (3.05\%), f. 9 (2.11\%), m. 4 (0.94\%) = "INSIGHT".

10. Creation, sport 2 [sport, athletic 1], running, easy climbing, absence of tension, habit, professionalism, work, magic trick 1 - 11 (2.58\%), f. 6 (1.4\%), m. 5 (1.17\%) = “ABILITY TO DO SOMETHING WITHOUT EFFORT OR STRAIN" (indicated as “ABSENCE OF TENSION" in Fig. 3).

11. Bright 2, playfulness, song, smile, flute, euphoria, humour 1 -8 (1.87\%), f. $8(1.87 \%)=$ "MANIFESTATION OF JOY".

12. Breath 3 [breath 2, to breathe 1], being, death, lifestyle 1 - 6 (1.4\%), f. 2 (0.47\%), m. 4 (0.94\%) = “ABSENCE OF DIFFICULTIES AND SUFFERING”.

13. The Unbearable Lightness of Being 3 [the unbearable lightness of being 2, unbearable 1], dissociation, duality, unusualness 1 - 6 (1.4\%), f. 5 (1.17\%), m. 1 $(0.23 \%)=$ "DUALITY". 
14. Bicycle 3 [bicycle, riding the bicycle at high speed, riding the bicycle at high speed in the forest 1], quickness, cars, promptitude 1 - 6 (1.4\%), f. 1 (0.23\%), m. 5 $(1.17 \%)=$ “SPEED".

15. Disengagement 3, naturalness, smoothly 1- 5 (1.17\%), f. 4 (0.94\%), m. 1 $(0.23 \%)=$ "DISENGAGEMENT".

16. Freshness [freshness, fresh air 1], purity 2 - 4 (0.94\%), f. $3(0.7 \%)$, m. 1 $(0.235 \%)=$ “FRESHNESS".

17. Enema 2, hunger, restroom 1- 4 (0.94\%), f. $2(0.47 \%)$, m. $2(0.47 \%)=$ “ABSENCE OF STOMACH HEAVINESS".

18. Madness, agile mind, mind $1-3(0.7 \%)$, m. $3(0.7 \%)=$ "LIGHTMINDEDNESS".

19. Children 2, youth 1 - 3 (0.7\%), f. 2 (0.47\%), m. 1 (0.235\%) = “A QUALITY TYPICAL OF CHILDHOOD AND YOUTH”.

20. Woman 2, young girl 1- 3 (0.7\%), f. 1 (0.23\%), m. 2 (0.47\%) = “A QUALITY OF A WOMAN OR A YOUNG GIRL”.

Figure 3.

The results of cluster analysis of the verbalised concept "lightness"

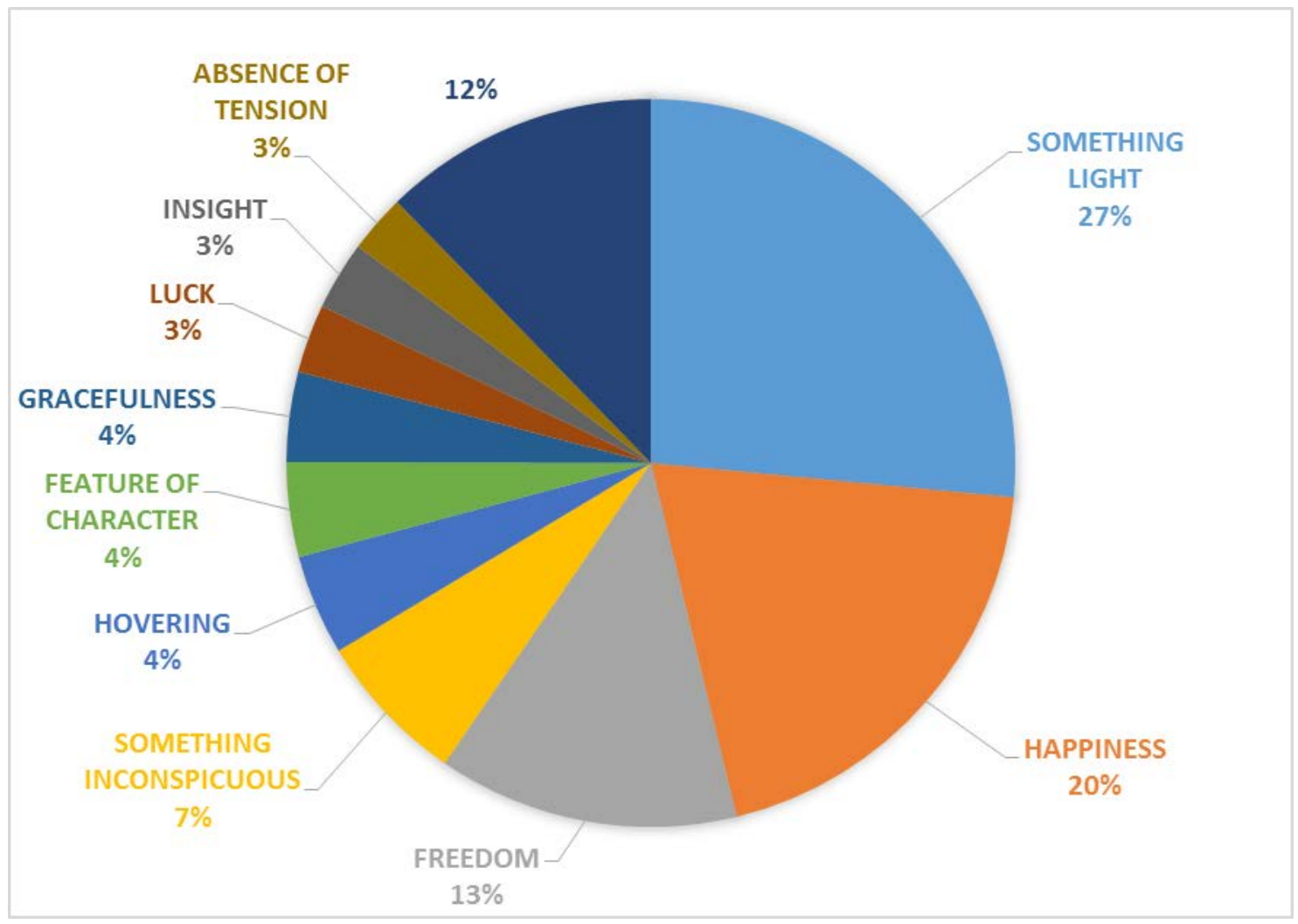


The diagram (Fig. 3) includes the first ten clusters that account for more than 2\%; the aggregate of clusters $11-20$ amount to $12 \%$ and are represented in the diagram as the eleventh cluster without a title.

The clusters described above do not contain reactions represented by antonyms: complexity $2-2$ (0.47\%), f. 1 (0.235\%), m. 1 (0.235\%); heaviness $2-2$ m. (0.47\%). Further interpretation of these reactions as the actualisation of the main differential seme of antonymic pairs - lightness-complexity, lightness-heaviness - will be provided while describing the psycholinguistic meanings.

In addition, the clusters contain reactions expressed by fixed phrases that give information about common idiomatic phrases with the stimulus, e.g. magic touch ("light hand" in Russian), quick money ("light money"), easy-going person ("light soul”), clear understanding ("light understanding"), athletic lightness, agile mind ("light mind"), light breath, the unbearable lightness of being, etc.

It is worth mentioning that the most complete and semantically adequate description of the concept "lightness" will be acquired only after its psycholinguistic meanings are described. This is due to the large number of polysemantic words among the reactions to the stimulus, e.g. freedom, happiness, joy, love, etc., which definitely made the task of distributing reactions by semantic groups more complicated. Certain semes may appear in the description of more than one psycholinguistic meaning.

\section{Discussion}

Regarding the free word association test with the stimulus word "lightness" in the Russian language, we are aware of research conducted by Russian scholars Karaulov, Cherkasova, Ufimtseva, Sorokin, Tarasov (Karaulov et al., 2002a, 2002b) in 1990s that described the results of the free word association test with the stimulus "lightness".

Below are the results of the associative field of the stimulus word "lightness" provided by the Russian Dictionary of Associations. We processed them in the same manner as it was described in part 3.4. of this article.

LIGHTNESS: in body 5; of soul, of behaviour, of gait, heaviness 4; in communication, of movement, of arms, of body 3; air, life, gait, bit of fluff 2; ballet, to run, fight, quickness, in movement, in movements, everywhere, of weight, joyfully, spring, wind, in everything, airiness, airy, balloon, in behaviour, during flight, during conversation, of spinning, grace, of a young girl, of actions, soul, of breath, naturalness, of life, of bone, lightly, of lying, incredible [lightness] of thoughts, of thought, filling the soul, being naive, being excited, unobtrusiveness, not for long, not difficult, relief, of communication, optimism, feeling, feather, personal computer, flight, of flight, of object, simply, of jump, freshness, power, state of body, happiness, of dance, body, surprising, of mind, of step, scarf, euphoria, Reebok 1; 104+74+0+60;

\footnotetext{
${ }^{7}$ Phrases in brackets are literal translations of Russian idiomatic expressions that contain the stimulus word.
} 
104 (number of respondents); 74 (number of unique reactions); 0 (number of declines); 60 (number of isolated cases) (Karaulov, 2002a, p. 289).

Here are some examples from the associative field in the reverse dictionary (from reactions to stimulus): LIGHTNESS $\leftarrow$ butterfly, difficulty 4; LIGHTNESS $\leftarrow$ carelessness, heaviness 2; LIGNTNESS $\leftarrow$ throw in the air, spring, air, hungry, to give, a girl, Everest, to experience, a sturdy fellow, to fly, to carry, to promise, relief, to hover, superficial, flight, flutters, flippant girl, fluff, freshness, free, athletic 1; 27+35 (Karaulov, 2002b, p. 381-382). As in the direct dictionary, figures after the stimulus indicate how often this word form appears in the dictionary entry of the corresponding stimulus. Two final figures in the end of the entry in the reverse dictionary $(27+35)$ indicate the total number of its occurrences in the dictionary (27) and the number of stimuli (or entries in the direct dictionary) that trigger this word form (35).

Comparative analysis of the associative fields of Ukrainian people and people who live in Russia reveals that the most frequent reaction in the Russian linguistic world-image is "IN BODY", i.e. feeling excited, cheerful, and full of energy, whereas Russian-speaking respondents from Ukraine tend to associate lightness with the feeling of freedom and absence of restrictions ("FREEDOM"). Diagram (Fig. 4) shows the number of common reactions.

Figure 4.

The results of the comparative analysis of the associative fields of the concept "lightness"

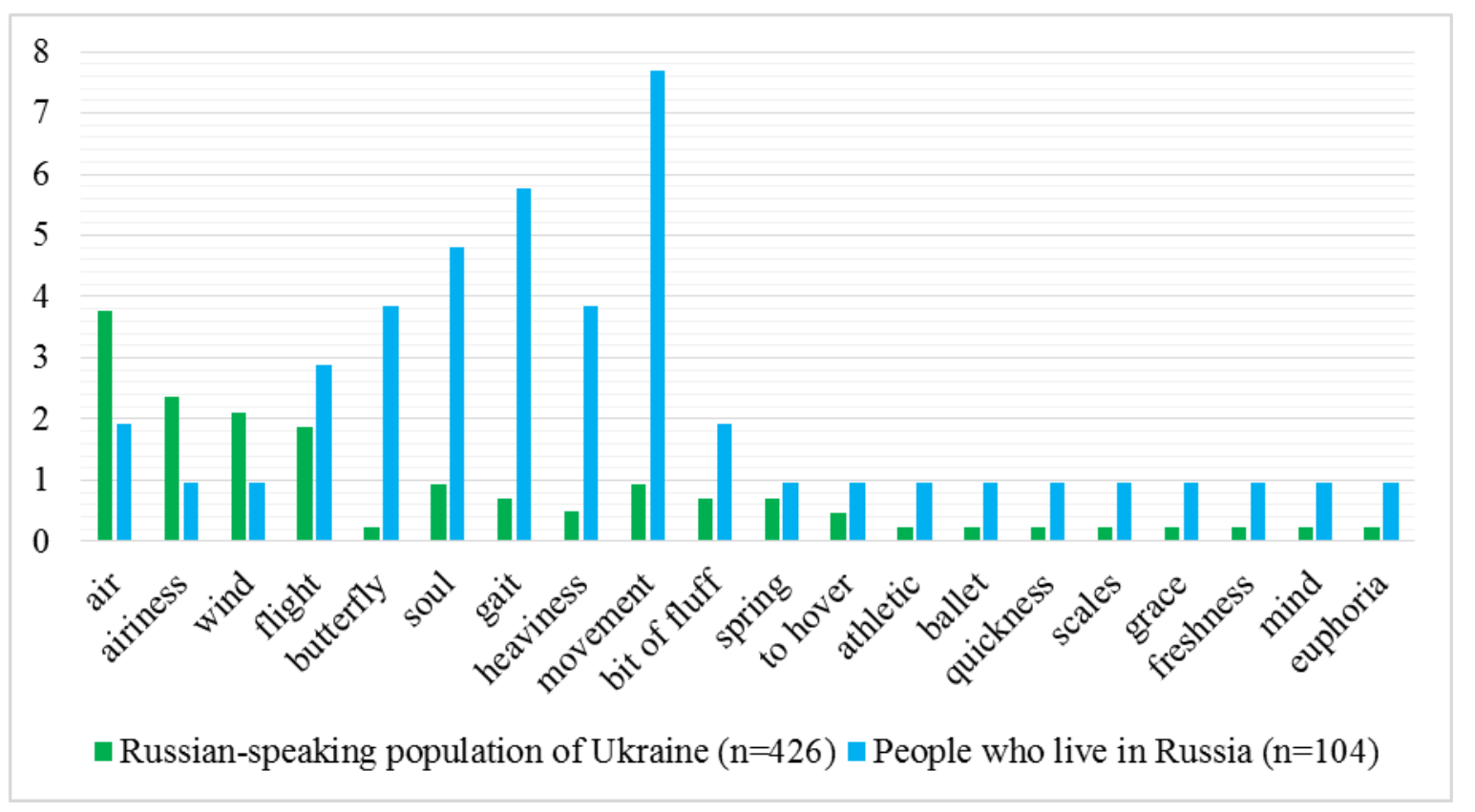

A distinctive feature of the Russian sample is the absence of negative reactions, while the Ukrainian sample features $1.9 \%$ of reactions with negative connotations; as well as a large number of reactions expressed by fixed phrases that give information 
about common idiomatic phrases with the stimulus - (lightness) of gait, (lightness) of behaviour, (lightness) in communication, (lightness) of movement, (lightness) of body, (lightness) in everything, etc.

Another characteristic feature of the Ukrainian sample is the ambivalent nature of the verbalised concept "lightness", which manifests itself in core clusters such as "the feeling of happiness and joyful ease" (20\%) and "the feeling of freedom (physical or mental), cheerfulness, excitement", as well as in the peripheral cluster "duality" $(1.4 \%)$.

In general, both samples display a wide semantic scope, strong synonymic and weak antonymic bonds between stimulus and reaction, positive attitude to the stimulus.

However, it should be noted that we use free word association test as a tool for clarifying and expanding our understanding of various notions, e.g. lightness as a component of ludic competence. Relying on the psycholinguistic meanings of playfulness that we described in our previous works (GordienkoMytrofanova et al., 2019) and on the results of cluster analysis presented in the current paper, we can define lightness (as a component of ludic competence) as the ability to dissociate oneself from a situation, keeping the state of inner freedom, to accept any outcome of this situation as potentially effective without clinging to hopes or expectations, and to adjust one's behaviour to changing circumstances. It is worth mentioning here that the semantic content of lightness as a component of ludic competence was defined on the basis of core clusters "the feeling of happiness and joyful ease", "the feeling of freedom (physical or mental), cheerfulness, excitement" and peripheral clusters - "ability to acquire something effortlessly, by good luck", "insight”, "ability to do something without effort or strain”, "duality”.

\section{Conclusions}

In the first place, the cluster analysis showed that the core (more than 10\%) of the verbalised concept "lightness" is represented by three semantic groups: "the quality being light and insignificant in weight and size; airiness, weightlessness" (27\%), "the feeling of happiness and joyful ease" (20\%), "the feeling of freedom (physical or mental), cheerfulness, excitement" (13\%). The last two clusters reveal the ambivalent character of the verbalised concept in the linguistic consciousness of the Russian speakers in Ukraine. On the one hand, the verbalised concept "lightness" is represented by lexemes that refer to having heart full of joy, lightheartedness, calm, appeasement, feeling comfort, silence, satisfaction, etc., but on the other hand, it is also represented by lexemes that refer to feeling cheerfulness, excitement, vigor, etc.

Secondly, the concept "lightness" displays a large variety of peripheral clusters (less than 10\%, but more than 1\%). Out of them, two clusters - "insight" and "duality" - deserve closer attention. The former reflects the cognitive component of lightness. The cluster with the arbitrary name "insight" accounts for mere 3\%, which testifies to the fact that Ukrainian respondents in the same way as their Russian counterparts do 
not tend to associate lightness with cognitive characteristics. The latter cluster, "duality", indirectly proves the ambivalent nature of the concept.

Thirdly, analysis of reactions produced by the Russian-speaking respondents from Eastern Ukraine did not reveal any significant difference between male and female samples. It means that the core semantic content of the concept "lightness" does not depend on gender identification. Clusters on the extreme periphery are exclusively represented either by female (e.g. "manifestation of joy") or male reactions (e.g. "lightmindedness"), which is most probably explained by individual preferences of usage rather than by gender-specific tendencies.

In the fourth place, comparative analysis of the verbalised concept lightness in the linguistic consciousness of Russian-speaking people from Ukraine and Russian, relying on the results of the frequency analysis (for five reactions, for the first reactions, as well as female and male associative fields) reveals a certain national-specific feature in the way how stimulus "lightness" is perceived. This was reflected in the most frequent reaction - "freedom". In this respect, a conclusion can be made that the concept "lightness" has a more prominent ambivalent nature and a bigger semantic scope in the linguistic consciousness of Ukrainian respondents.

Finally, it is worth mentioning once again that the results of the free word association test with the stimulus word "lightness" was applied in order to define the semantic content of lightness as a component of ludic competence considering both core and peripheral clusters.

As for the prospect of further research, we believe it is necessary, in the first place, to describe the psycholinguistic meanings of the stimulus "lightness" in order to receive a more complete model of the systemic meaning of the word "lightness". Besides, it appears necessary to describe the behavioural pattern of the ludic position "Balance-Master" in the framework of ludic competence training sessions, taking into consideration core and peripheral semes of the concept "lightness". The research also proves the efficiency of free association test as a psycholinguistic tool for clarifying and expanding our understanding of various notions.

\section{References}

Barnett, L. (2007). The nature of playfulness in young adults. Personality and Individual Differences, 43, 949-958. https://doi.org/10.1016/j.paid.2007.02.018

Bowman, J. (1987). Making Work Play. In G. A. Fine (Ed.), Meaningful Play, Playful Meanings (pp. 61-71). Champaign, IL: Human Kinetics.

Bundy, A. (1996). Play and Playfulness: What to Look for. In D.L. Parham \& L. S. Fazio (Eds.), Play in Occupational Therapy for Children (pp. 52-66). St. Louis, MO: Mosby.

Chapman, J. (1978). Playfulness and the development of divergent thinking abilities. Child: Care, Health and Development, 4, 371-383. https://doi.org/10.1111/j.1365-2214.1978.tb00096.x

Csikszentmihalyi, M. (1975). Play and intrinsic rewards. Journal of Humanistic Psychology, 15, 41-63. https://doi.org/10.1111/j.1365-2214.1978.tb00096.x 
Dal, V. I. (2011). Tolkovyi Slovar Zhivogo Velikorusskogo Yazyka [Explanatory Dictionary of the Living Great Russian Language]: in four volumes. Moscow: Publishing house: Drofa.

Glynn, M., \& Webster, J. (1992). The adult playfulness scale: an initial assessment. Psychological Reports, 71(1), 83-103. https://doi.org/10.2466/pr0.1992.71.1.83

Gordienko-Mytrofanova, I., \& Kobzieva, Iu. (2017). Playful competence: the access code to the inner resources. Proceedings of the 15th European Congress of Psychology Amsterdam, 11-14 July (19).

Gordienko-Mytrofanova, I., Pidchasov, Ye., Sauta, S., \& Kobzieva, Iu. (2018). The problem of sample representativeness for conducting experimental and broad psychological research. Psycholinguistics-Psiholingvistika, 23(1), 11-46. https://doi.org/10.5281/zenodo.1212360

Groos, K. (1976). The Play of Man: Teasing and Love-Play. In J. Brunner, A. Jolly, \& K. Sylva (Eds.), Play, Development and Evolution (pp. 62-83). Middlesex, United Kingdom: Penguin Books.

Guitard, P., Ferland, F. \& Dutil, É. (2005). Toward a better understanding of playfulness in adults. OTJR: Occupation, Participation and Health, 25(1), 9-22. https://doi.org/10.1177/153944920502500103

Кобзева, Ю., Гордиенко-Митрофанова, И., Гончаренко-Кулиш, А. (2020а). Определение шаловливости как компонента игровой компетентности через реконструкцию семантических элементов концепта «шаловливость». Проблеми сучасної психологіï, 47, $118-140$.

Kobzieva Iu., Gordienko-Mytrofanova I., Sauta S. (2020b). Psycholinguistic Features of Imagination as a Component of Ludic Competence. EUREKA: Social and Humanities. Psychology, 2, 1523. http://dx.doi.org/10.21303/2504-5571.2020.001128

Kobzieva Iu., Gordienko-Mytrofanova I., Udovenko M., Sauta S. (2020c). Concept "humour” in the linguistic consciousness of the Russian-speaking population of Ukraine. European Journal of Humour Research, 8(1), 29-44. http://dx.doi.org/10.7592/EJHR2020.8.1.kobzieva

Караулов Ю. Н., Черкасова Г. А., Уфимцева Н. В., Сорокин Ю. А., Тарасов Е. Ф. Русский ассоциативный словарь. В 2-х т. T. І. От стимула к реакиии: ок.7000 стимулов. М.: ООО «Издательство Астрель»: ООО «Издательство АСТ».

Караулов Ю. Н., Черкасова Г. А., Уфимцева Н. В., Сорокин Ю. А., Тарасов Е. Ф. Русский ассоциативный словарь. В 2-х т. Т. ІІ. От реакции к стимулу: более 100000 реакций. М.: ООО «Издательство Астрель»: ООО Издательство АСТ».

Ожегов, С. И., Шведова, Н. Ю. (2011). Толковый словарь русского языка. Москва: Мир и образование, Оникс.

Попова, З. Д., Стернин, И. А. (2007). Семантико-когнитивный анализ языка. Воронеж: Истоки. Proyer, R. (2012). Development and initial assessment of a short measure for adult playfulness: The SMAP. Personality and Individual Differences, 53(8), 989-994. https://doi.org/10.1016/j.paid.2012.07.018

Proyer, R. (2017). A new structural model for the study of adult playfulness: Assessment and exploration of an understudied individual differences variable. Personality and Individual Differences, 108, 113-122. https://doi.org/10.1016/j.paid.2016.12.011

Raven, J. (2001). The Conceptualisation of Competence. New York: Peter Lang Publishing,Inc. Schaefer, C. \& Greenberg, R. (1997). Measurement of playfulness: a neglected therapist variable. International Journal of Play Therapy, 6(2), 21-31. https://doi.org/10.1037/h0089406

Shen, X. (2010). Adult Playfulness as a Personality Trait: Its Conceptualization, Measurement, and Relationship to Psychological Well-Being. (Doctoral dissertation). Retrieved from Pennsylvania State University Library Catalog (OCLC No. 859524715) 
Shen, X., Chick, G. \& Zinn, H. (2014). Playfulness in adulthood as a personality trait: a reconceptualization and a new measurement. Journal of Leisure Research, 46(1), 58-83. https://doi.org/10.1080/00222216.2014.11950313

Стернин, И. А., Рудакова, А. В. (2011). Психолингвистическое значение слова и его описание. Воронеж: Ламберт.

Tsuji, Hit., Tsuji, Hei., Yamada, S., Natsuno, Y., Morita, Y., Mukoyama, Y., Hata, K. \& Fujishima, Y. (1996). Standardization of the Five Factor Personality Questionnaire: Factor structure. International Journal of Psychology, 31. Proceedings from the XXVI International Congress of Psychology. Montreal, 16-21August. (103-217).

Уфимцева, Н. (2009). Образ мира русских: системность и содержание. Язык и культура, 98-111.

Ушаков, Д. Н. (1935-1940). Толковый словарь русского языка: в четырех томах. Москва: Сов.энциклопедия: ОГИЗ.

Yarnal, C. \& Qian, X. (2011). Older-adult playfulness: an innovative construct and measurement for healthy aging research. American Journal of Play, 4(1), 52-79. Retrieved from https://files.eric.ed.gov/fulltext/EJ985548.pdf

Ефремова, Т. Ф. (2000). Новый словарь русского языка. Толково-словообразовательньй. Москва: Русский язык.

Епишкин, Н. И. (2010). Историчесикй словарь галлицизмов русского языка. Москва: Словарное издательство ЭТС.

Yue, X., Leung, C. \& Hiranandani, N. (2016). Adult playfulness, humor styles, and subjective happiness. Psychological Reports, 119(3), 630-640. https://doi.org/10.1177/0033294116662842

Засекина, Л. В. (2008). Тенденції розвитку вітчизняної психолінгвістики: методологічний огляд проблем та окреслення шляхів їх вирішення. Психолінгвістика, 1. C. 9-20. Retrieved from http://nbuv.gov.ua/UJRN/psling_2008_1_2

\section{References (translated and transliterated)}

Barnett, L. (2007). The nature of playfulness in young adults. Personality and Individual Differences, 43, 949-958. https://doi.org/10.1016/j.paid.2007.02.018

Bowman, J. (1987). Making Work Play. In G. A. Fine (Ed.), Meaningful Play, Playful Meanings (pp. 61-71). Champaign, IL: Human Kinetics.

Bundy, A. (1996). Play and Playfulness: What to Look for. In D.L. Parham \& L. S. Fazio (Eds.), Play in Occupational Therapy for Children (pp. 52-66). St. Louis, MO: Mosby.

Chapman, J. (1978). Playfulness and the development of divergent thinking abilities. Child: Care, Health and Development, 4, 371-383. https://doi.org/10.1111/j.1365-2214.1978.tb00096.x

Csikszentmihalyi, M. (1975). Play and intrinsic rewards. Journal of Humanistic Psychology, 15, 41-63. https://doi.org/10.1111/j.1365-2214.1978.tb00096.x

Dal, V. I. (2011). Tolkovyi Slovar Zhivogo Velikorusskogo Yazyka [Explanatory Dictionary of the Living Great Russian Language]: in four volumes. Moscow: Publishing house: Drofa.

Glynn, M., \& Webster, J. (1992). The adult playfulness scale: an initial assessment. Psychological Reports, 71(1), 83-103. https://doi.org/10.2466/pr0.1992.71.1.83

Gordienko-Mytrofanova, I., \& Kobzieva, Iu. (2017). Playful competence: the access code to the inner resources. Proceedings of the 15th European Congress of Psychology Amsterdam, 11-14 July (19).

Gordienko-Mytrofanova, I., Pidchasov, Ye., Sauta, S., \& Kobzieva, Iu. (2018). The problem of sample representativeness for conducting experimental and broad psychological research. Psycholinguistics, 23(1), 11-46. https://doi.org/10.5281/zenodo.1212360 
Groos, K. (1976). The Play of Man: Teasing and Love-Play. In J. Brunner, A. Jolly, \& K. Sylva (Eds.), Play, Development and Evolution (pp. 62-83). Middlesex, United Kingdom: Penguin Books.

Guitard, P., Ferland, F. \& Dutil, É. (2005). Toward a better understanding of playfulness in adults. OTJR: Occupation, Participation and Health, 25(1), 9-22.

https://doi.org/10.1177/153944920502500103

Кобзева, Ю., Гордиенко-Митрофанова, И., Гончаренко-Кулиш, А. (2020а). Определение шаловливости как компонента игровой компетентности через реконструкцию семантических элементов концепта «шаловливость». Проблеми сучасної психологї, 47, $118-140$.

Kobzieva, Iu., Gordienko-Mytrofanova, I., Goncharenko-Kulish, A. (2020a). Opredeleniie shalovlivosti kak komponenta igrovoi kompetentosti cherez rekonstruktsiiu semanticheskikh elementov kontsepta "shalovlivost" [Defining impishness as a component of ludic competence via restructuring semantic elements of the concept "impishness"]. Problemy Suchasnoi Psykholohii - Problems of Modern Psychology, 47, 118-140. https://doi.org/10.32626/22276246.2020-47

Kobzieva Iu., Gordienko-Mytrofanova I., Sauta S. (2020b). Psycholinguistic Features of Imagination as a Component of Ludic Competence. EUREKA: Social and Humanities. Psychology, 2, 15-23. http://dx.doi.org/10.21303/2504-5571.2020.001128

Kobzieva Iu., Gordienko-Mytrofanova I., Udovenko M., Sauta S. (2020c). Concept "humour” in the linguistic consciousness of the Russian-speaking population of Ukraine. European Journal of Humour Research, 8(1), 29-44. http://dx.doi.org/10.7592/EJHR2020.8.1.kobzieva

Karaulov, Yu. N., Cherkasova, G. A., Ufimtseva, N. V., Sorokin, Yu. A., \& Tarasov, Ye. F. (2002a). Russkii Assotsiativnyi Slovar [Russian Associative Vocabulary], Vol. 1. Ot reaktsii k stimulu [From Reaction to Stimulus], ca. 100000 reactions. Moscow: LLC Astrel Publishers; LLC AST Publishers.

Karaulov, Yu. N., Cherkasova, G. A., Ufimtseva, N. V., Sorokin, Yu. A., \& Tarasov, Ye. F. (2002b). Russkii Assotsiativnyi Slovar [Russian Associative Vocabulary], Vol. 2. Ot stimula k reaktsii [From Stimulus to Reaction], ca. 7000 stimuli. Moscow: LLC Astrel Publishers; LLC AST Publishers.

Ожегов, С. И., Шведова, Н. Ю. (2011). Толковый словарь русского языка. Москва: Мир и образование, Оникс.

Ozhegov, S. I. \& Shvedova, N. Yu. (2011). Tolkovyi Slovar Russkogo Yazyka [Dictionary of Russian Language]. Moscow: Mir i Obrazovaniie, Oniks.

Попова, 3. Д., Стернин, И. А. (2007). Семантико-когнитивный анализ языка. Воронеж: Истоки.

Popova, Z. D. \& Sternin, I. A. (2007). Semantiko-Kognitivnyi Analiz Yazyka [Semantic and Cognitive Analysis of Language]. Voronezh: Istoki.

Proyer, R. (2012). Development and initial assessment of a short measure for adult playfulness: The SMAP. Personality and Individual Differences, 53(8), 989-994. https://doi.org/10.1016/j.paid.2012.07.018.

Proyer, R. (2017). A new structural model for the study of adult playfulness: Assessment and exploration of an understudied individual differences variable. Personality and Individual Differences, 108, 113-122. https://doi.org/10.1016/j.paid.2016.12.011

Raven, J. (2001). The Conceptualisation of Competence. New York: Peter Lang Publishing,Inc. Schaefer, C. \& Greenberg, R. (1997). Measurement of playfulness: a neglected therapist variable. International Journal of Play Therapy, 6(2), 21-31. https://doi.org/10.1037/h0089406 
Shen, X. (2010). Adult Playfulness as a Personality Trait: Its Conceptualization, Measurement, and Relationship to Psychological Well-Being. (Doctoral dissertation). Retrieved from Pennsylvania State University Library Catalog (OCLC No. 859524715)

Shen, X., Chick, G. \& Zinn, H. (2014). Playfulness in adulthood as a personality trait: a reconceptualization and a new measurement. Journal of Leisure Research, 46(1), 58-83. https://doi.org/10.1080/00222216.2014.11950313

Sternin, I. A., \& Rudakova, A. V. (2011). Psikholingvisticheskoie znacheniie slova i yego opisaniie [Psycholinguistic meaning of the word and its description]. Voronezh: Lambert

Tsuji, Hit., Tsuji, Hei., Yamada, S., Natsuno, Y., Morita, Y., Mukoyama, Y., Hata, K. \& Fujishima, Y. (1996). Standardization of the Five Factor Personality Questionnaire: Factor structure. International Journal of Psychology, 31. Proceedings from the XXVI International Congress of Psychology. Montreal, 16-21August. (103-217).

Ufimtseva, N. (2009). Obraz mira russkikh: sistemnost i soderzhaniie [Image of the world of Russians: the systemic characteristics and the content]. Yazyk i Kultura - Language and Culture, 98-111.

Ushakov, D. N. (Ed.). (1935-1940). Tolkovyi Slovar Russkogo Yazyka [Dictionary of Russian Language]: in four volumes. Moscow: Sov. Encyclopedia: OGIZ. Retrieved from http://febweb.ru/feb/ushakov/ush-abc/0ush.htm

Yarnal, C. \& Qian, X. (2011). Older-adult playfulness: an innovative construct and measurement for healthy aging research. American Journal of Play, 4(1), 52-79. Retrieved from https://files.eric.ed.gov/fulltext/EJ985548.pdf

Yefremova, T. F. (2000). Novyi Slovar Russkogo Yazyka. Tolkovo-Slovoobrazovatelnyi [New Dictionary of the Russian Language. Interpretative and Derivational]. Moscow: Russkii yazyk. Retrieved from https://www.efremova.info/

Yepishkin, N. I. (2010). Istoricheskii slovar gallitsizmov russkogo yazyka [Historical Dictionary of Gallicisms in the Russian Language]. Moscow: ETS Dictionary Publishing House. Retrieved from http://rus-yaz.niv.ru/doc/gallism-dictionary/index.htm

Yue, X., Leung, C. \& Hiranandani, N. (2016). Adult playfulness, humor styles, and subjective happiness. Psychological Reports, 119(3), 630-640. https://doi.org/10.1177/0033294116662842

Zasiekina, L. V. (2008). Tendentsiii rozvytku vitchyznianoii psykholingvistyky: metodolohichnyi ohliad problem ta okreslennia shlyakhiv yikh vyrishennia [Trends in the development of national psycholinguistics: a methodological overview of problems and outlining ways to solve them]. Psycholinguistics, 1, 9-20. Retrieved from http://nbuv.gov.ua/UJRN/psling_2008_1_2 